\title{
Modification of Conodont element micro-ornamentation by clay-mineral indentation.
}

\author{
R. D. BURNETT ${ }^{1}$ AND R. L. AUSTIN ${ }^{2}$ \\ 'Department of Geology, Trinity College, Dublin 2; \\ ${ }^{2}$ Department of Geology, University of Southampton, SO9 5NH
}

\begin{abstract}
Sclerites', described from the surfaces of conodont elements in bedding-plane assemblages by Rhodes and Austin (1985), are shown to be indentations of bladed minerals on the conodont element apatite. Such minerals are seen coating moulds from which conodont elements have been removed, and are identified tentatively as Kaolinite. The recognition of inorganically-produced surface patterns on conodont elements, developed within low thermal régimes, is considered relevant in the light of recent studies of biogenic and metamorphic surface features.
\end{abstract}

\section{INTRODUCTION}

In a comprehensive study of conodont element beddingplane assemblages from the Carboniferous of Britain, Rhodes and Austin (1985) described one fauna having surfaces covered in minute elongate marks, which they tentatively called sclerites. The term 'indentation' is used here since 'sclerite' has already been applied by Melton and Scott (1973) in a different context. Prof Lindstrom (pers.comm.) has suggested that they represent the impression on the conodont apatite of clay minerals. The specimen concerned (catalogued as assemblage WE 1862 in collection of the British Geological Survey, Nottingham) was obtained from marine shale in the Westphalian B (base) Vanderbeckei Marine Band at Sherwood Colliery, Nottinghamshire.

The assemblage includes approximately six overlapping Hi elements and two Sp elements of the Idiognathodus type, occurring in close association on the bedding surface. Rhodes and Austin (1985) recorded the colour of the conodont elements (since obscured by gold-palladium coating) as black, presumably corresponding to Epstein et al.s (1977) conodont Colour Alteration Index 5, suggesting a high level of organic maturation. CAI 2 is the typical maturity level in the Nottingham area, so possibly the original colour appraisal of the assemblage reflects in part the shale backing of the in-situ conodont elements. If a CAI of 2 is correct, it implies limited burial metamorphism of the specimen, and subjection to temperatures within the lower end of the range $60^{\circ}-140^{\circ} \mathrm{C}$ (Epstein et al., 1977).

\section{DESCRIPTION AND INTERPRETATION}

The conodont elements of assemblage WE 1862 are flatlying ramiform elements encased in a coarse clay (shale) matrix, against which the surfaces of the conodont elements appear smooth (Plate 1, Fig. 1). Under high power magnification (Plate 1, Fig. 2), a typical conodont element is ornamented with both striations on the denticles and small irregularly-oriented indentations concentrated on the main bar. The striations are a characteristic feature on denticles of hindeodellid-type conodont elements, the bar typically appearing smooth even at high magnifications. The indentations are not restricted to the bar, and elsewhere are seen distributed over the denticles (Plate 1, Fig. 3), masking the original ornament of striae. In detail, the indentations are lath-shaped, elongate depressions typically between $0.7 \mu \mathrm{m}$ and $2 \mu \mathrm{m}$ long, $0.2 \mu \mathrm{m}$ wide and perhaps $0.2 \mu \mathrm{m}$ deep, the 'ends' of each indentation appearing either square to subrounded or tapering to a sharp angle (Plate 1, Fig. 4). There is no apparent preferred orientation or area variation in size of the indentations, and the latter do not continue into the surrounding shale, occurring only on the conodont elements of the assemblage.

EDX analyses indicate that the indentations on the conodont element surfaces (Plate 1, Figs. 2-4) are depressions in the conodont apatite rather than an irregular coating of adherent mineral (Figs. 1,2). EDX spectra from one of the indentation marks illustrated (Plate 1, Fig. 4) show dominant calcium peaks, a large phosphorous peak (partly masked by the gold coating), smaller iron peaks and a minor silica peak (Fig. 1A). A scaled up-run (Fig. 1B) illustrates differentiation of the phosphorus peak from the gold peak, underlining the high concentration of the former. The dominance of calcium and phosphorus almost certainly show the indentations to be defined by apatite (Pietzner et al., (1968) recognised conodont apatite as a francolite). Minor iron and silica peaks indicate small amounts of adherent material, possibly as a very fine coating, though the $\mathrm{Ca} / \mathrm{P}$ element map of Fig. 2 shows that the conodont elements are not substantially overlain by any nonphosphatic mineral.

The shale surrounding the conodont elements consists of flaky clay minerals (Plate 1, Fig. 9) the morphology of which makes them unlikely precursors for the indentation patterns. EDX spectra for these clays (Fig. 1C) show a calcium/ironrich aluminium silicate composition, with subsidiary 

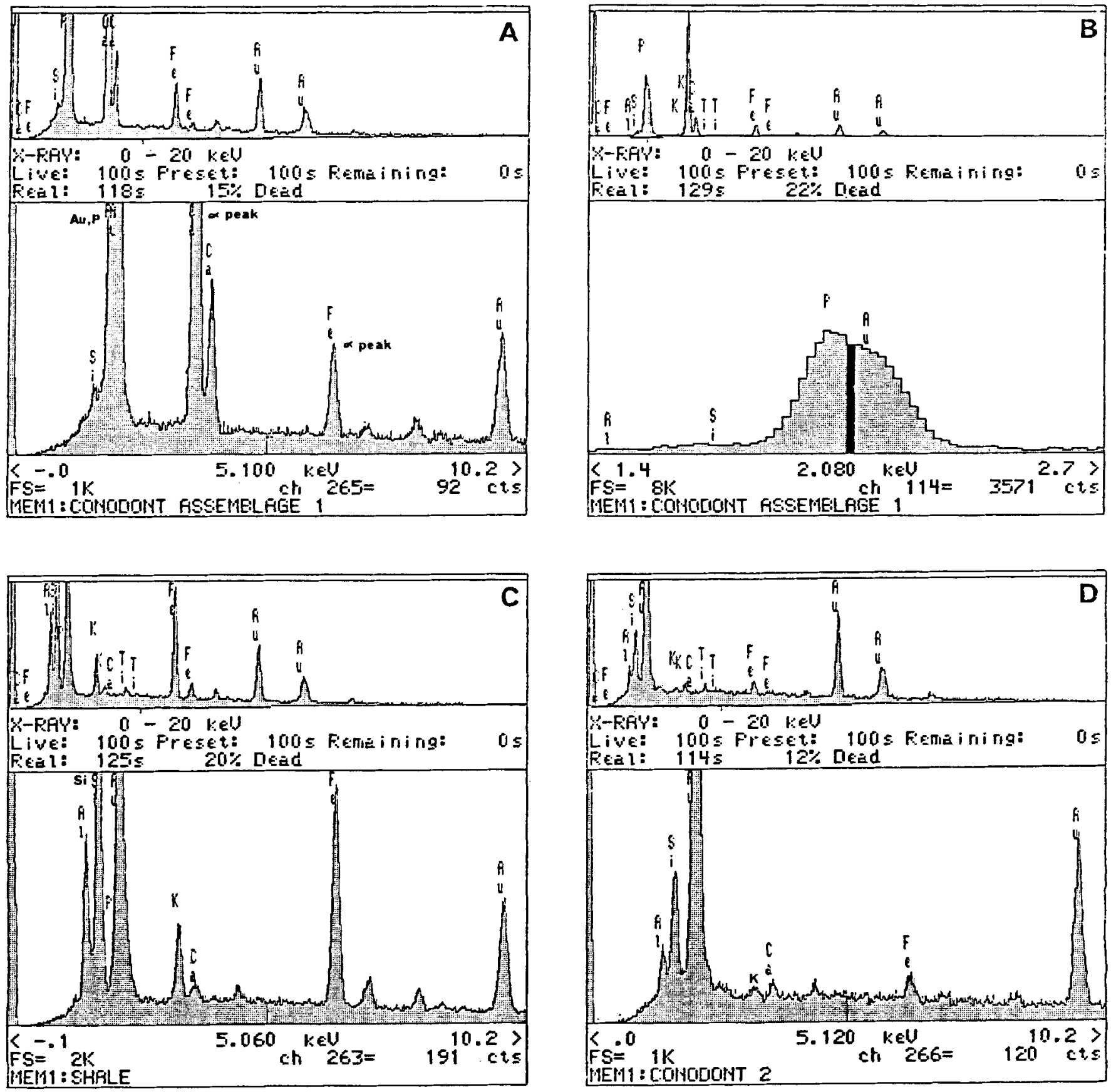

Fig. 1. EDX Analyses of Materials from Assemblage WE 1862

A: EDX analyses of elongate impressions in Plate 1, Fig. 4. Despite some masking of signals by gold coating, calcium and phosphorous peaks dominate, suggesting apatite, whilst iron and ? silica concentration probably represent traces of adherent material.

B: EDX analysis modified from Fig. 1A to show details of gold/phosphorous peak complex and delineation of the two elements.

C: EDX analysis of clay minerals in shale (see Plate 1, Fig. 9). Silica and aluminium dominate, with high concentrations of iron and potassium.

D: EDX analysis of mineral coating mould in Plate 1, Figs. 5-7. Despite increased overprinting of gold peak, silica and aluminium dominate, and there appears to be a lesser presences of potassium and iron than in Fig. $1 \mathrm{C}$. 


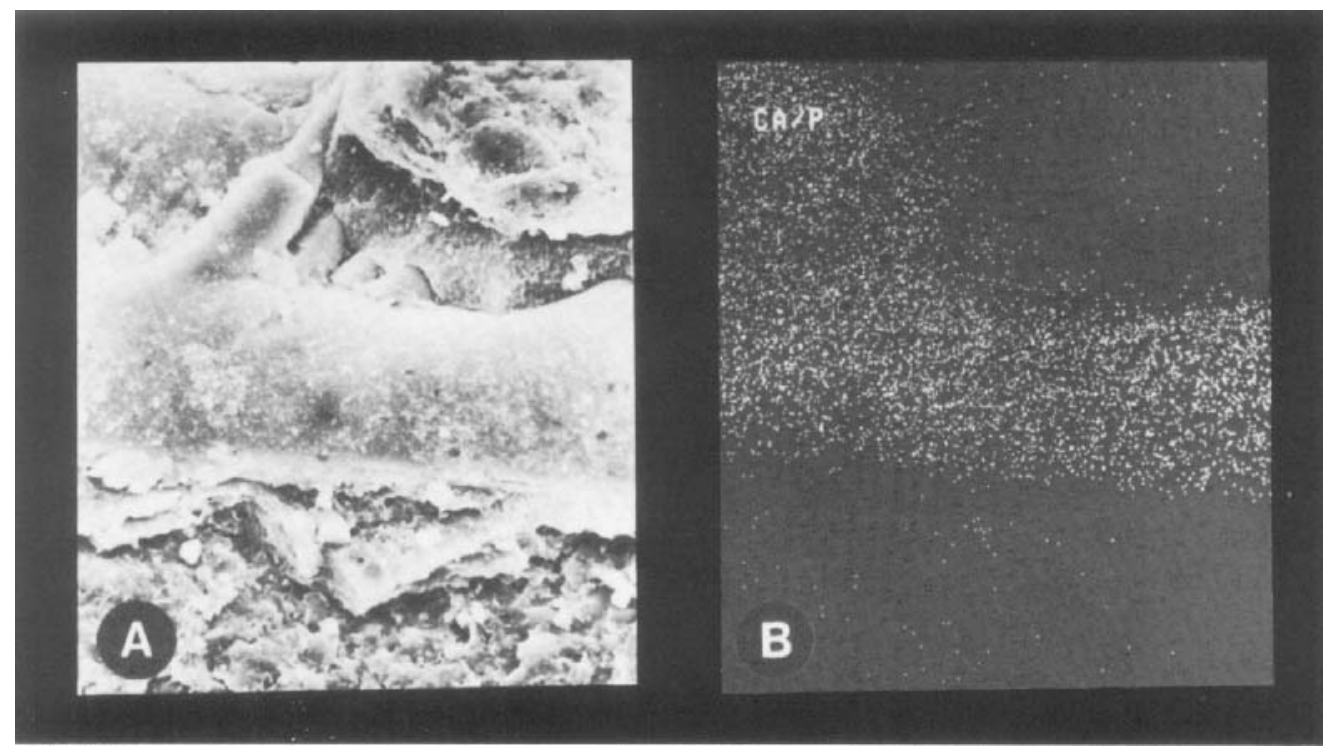

Fig. 2. Calcium/Phosphorous Element Map of Hindeodellids from Assemblage WE1862.

A: Portion of hindeodellid, overlapping blade of platform conodont (top left) and surrounded by clay minerals (bottom and top right). $x 800$.

$\mathrm{B}$ : Ca/P EDX concentration map illustrating absence of mineral coating on conodonts. $x 800$.

potassium. Comparison with the figures and spectra of Welton (1984) suggest an illite-smectite mixed-layer clay, the high iron content due to amorphous iron oxide coatings.

Part of the assemblage consists of impressions left by conodont elements lost during original preparation (Plate 1, Fig. 5), lined with material of suitable morphology (Plate 1, Figs. 6,7$)$ to have been the template for the conodont indentations. Plate 1, Fig. 5 shows the mould of a bar element, coated with smooth mineral (compared with the coarse surrounding clays) over the depressed area previously occupied by the main bar of the conodont element, but uncoated in the depressions left by the denticles.

The mineral coating (Plate 1, Fig. 6) comprises a relatively continuous layer $2-2.5 \mu \mathrm{m}$ thick, overlying the irregular clay crystals of the shale matrix. The surface of the coating is patterned with positive elongate structures, $1.5-2 \mu \mathrm{m}$ long by $0.2-0.3 \mu \mathrm{m}$ wide (Plate 1, Fig. 7), mirroring the size and shape of the indentations (Plate 1, Fig. 4), and it is these structures which are concluded to have caused the indentations. They show little or no preferred orientation or any significant morphological variation over the coating, neither are they developed within the shale matrix proper.

These positive elongate structures (Plate 1, Fig. 7) are interpreted either as small subhedral tabular crystals or to represent the thin edges of platy crystals. EDX spectra of the coating (Fig. 1D) are similar to those of the shale matrix, but with very little potassium which, tied to the morphology of the crystals, suggests perhaps a coating of authigenic chlorite. Given the low diagenetic rank of the specimen (C.A.I. 2), authigenic chlorite is perhaps unlikely. Another possibility for the coating mineral is kaolinite. This has a low potassium content, is stable at the relevant P-T conditions and has often been observed as shell infills (pers comm. Prof. A. Spears).

The interpretation is therefore one of a coating of irregularly oriented clay (? kaolinite) flakes, their edges in contact with the conodont element surface. The envisaged arrangement of such coating, if seen from the 'underside' (the underside of the mould in Plate 1, Fig. 6) would be similar to that of the clay minerals figured by Welton (1984) and Gillott (1986) with polygonal flakes irregularly distributed over a surface, their 'thin' edges parallel with the conodont element surface and the 'flat' edges normal to it.

Growth of the mineral appears to have been at the expense of the conodont element surface, with apatite solution allowing indentation by aggressive clay mineral growth during diagenesis. Morton (1986) states that dissolution of detrital apatites may occur very early on in sediment diagenesis, through penetration of low $\mathrm{Ph}$ meteoric groundwaters, and the process of clay-mineral indentation is likewise thought to be an early one. These features are consistent with kaolinite formation. Evidence for solution of apatite is shown by other conodont elements in the assemblage, which display finescale developments of recrystallised appatite prisms arrayed over normally smooth denticles (Plate 1, Fig. 8).

An alternative interpretation of the indentations is suggested by their superficial resemblance to structures recognised by Clark (1989) as fossil bacteria. Clark (1989) described a coprolitic assemblage of conodont elements, the latter coated in mineralised bacteria similar in scale and morphology to the mineral material of Plate 1, Fig. 7, and noted etch patterns on the conodont element surfaces mimicking the bacteria. If the indentations and coating material on Assemblage WE1 862 do 
reflect a bacterial influence, two points are raised. Firstly, Clark's (1989) suggestion that the bacteria he described originated in a conodontophage's gut, and from there was incorporated in the coprolitic material enclosing the conodont elements, is open to question. There is no suggestion that the material in assemblage WE1862 represents a coprolitic association, so it may be that the bacteria of Clark (1989), if the same as the structures described here, are of a more ubiquitous origin. Secondly, the discrete mineral layer (Plate 1, Fig. 6) containing bladed mineral grains, or possibly of bacteria, are of a composition distinct from the bulk of the shale matrix, and the conclusions of preceding sections remain valid.

However, the indentations and their template (Plate 1, Fig. $4,7)$ are both more irregularly elongate and more angular than the semi-ovoid bacterial structures of Clark (1989). So the interpretation of a clay mineral-related origin for the indentations is retained, at least in the light of available evidence.

That similar indentations have not been reported previously reflects both that conodont elements are much more frequently extracted from limestones than shales, and that until recently, the magnifications used in S.E.M. studies of conodont element surfaces were too low to record such patterning.

\section{SIGNIFICANCE}

The indentations described from conodont element surfaces are ascribed to aggressive growth of clay minerals during diagenesis at relatively low temperatures $\left(60^{\circ} \mathrm{C}-14^{\circ} \mathrm{C}\right.$ for CAI2). Recognition of such abiogenic 'ornament' is important that it may not be confused with, and possibly interpreted as, either biogenic ornament or the metamorphic recrystallization textures of conodonts, both of which are currently receiving much attention.

\section{ACKNOWLEDGEMENTS}

The authors wish to thank the British Geological Survey, in particular Dr. Ivimey-Cook, for loan of the material. Additionally, we gratefully acknowledge the help of Colin Reid of the S.E.M. unit and Mairéad Rutherford of the
Applied Geology Unit, Trinity College, Dublin. This manuscript benefited from reading and comments by Professor Alan Spears (Sheffield) and Dr. Alan Higgins (B.P., Sunbury). R.B. is in receipt of a Department of Education Postdoctoral Fellowship.

\section{Manuscript received January 1989 \\ Revised manuscript accepted October 1989}

\section{REFERENCES}

Clark, N. D. L., 1989 Carboniferous coprolitic bacteria from the Ardross Shrimp Bed, Fife, Scott. J. Geol. 25, 99-104.

Epstein, A. G., Epstein, J. B., \& Harris, L. D., 1977. Conodont color alteration - an index to organic metamorphism. U.S.G.S. Prof. Pap., Washington, 995, 1-27.

Gillott, J. E., 1986, Some clay-related problems in engineering geology in North America. Clay Minerals, London,21, 261278.

Melton, W. G., Jr., \& Scott, H. W., 1973. Conodont - bearing animals from the Bear Gulch Limestone, Montana, Geol. Soc. Am. Spec. Pap., Boulder, Colorado, 141, 31-65.

Morton, A. C., 1986. Dissolution of apatite in North Sea Jurassic sandstones; implications for the generation of secondary porosity. Clay Minerals, London, 21, 711-733.

Pietzner, H., Vahl, J., Werner, H., \& Ziegler, W., 1968. Zur chemischen Zusammensetzung und Mikromorphologie der Conodonten. Palaeontographica, Stuttgart,128, 115-152.

Rhodes, F. H. T., \& Austin, R. L., 1985. Conodont assemblages from the Carboniferous of Britain. Compte Rendu 9ieme Congr. Int. Strat.Geol. Carbonifere, Illinois 1979, 5, 287 300.

Welton, J. E., 1984. S.E.M. Petrology Atlas, Methods in Exploration Series, A.A.P.G., Tulsa, Oklahoma, 237p

\section{Explanation of Plate 1}

Fig. 1 Part of assemblage WE 1862, showing Hi (hindeodellid) elements of Idiognathodus x 250.

Fig. 2 Detail of striae-ornamented denticles, and main bar (base of picture) indented with unoriented elongate mineral impressions. $\mathrm{x} 3500$.

Fig. 3 Hindeodellid denticle, irregularly marked with elongate impressions. x 7000 .

Fig. 4 Detail of elongate mineral impressions arrayed over bar of Plate 1, Fig. 2. Impressions are roughly lath-shaped and of the same magnitude. $x 8000$.

Fig. 5 Mould left by ramiform element in assemblage WE 1862, lined with finely crystalline mineral and surrounded by irregular large clays of the shale matrix. x 700 .

Fig. 6 Edge of mould, with upper surface comprising small elongate tabular crystals, or crystal 'edges' of platey mineral arranged normal to the mould surface. $\mathrm{x} 4000$.

Fig. 7 Mould surface, showing arrangement of elongate crystals ór crystal edges (cf. Plate 1, Fig. 4). x 8000.

Fig. 8 Diminutive, semi-euhedral apatite prisms coating surface of a ramiform conodont element in assemblage WE 1862, evidencing diagenetic recrystallization. $x 8000$.

Fig. 9 Clay mineral components of shale. $x 3500$. 


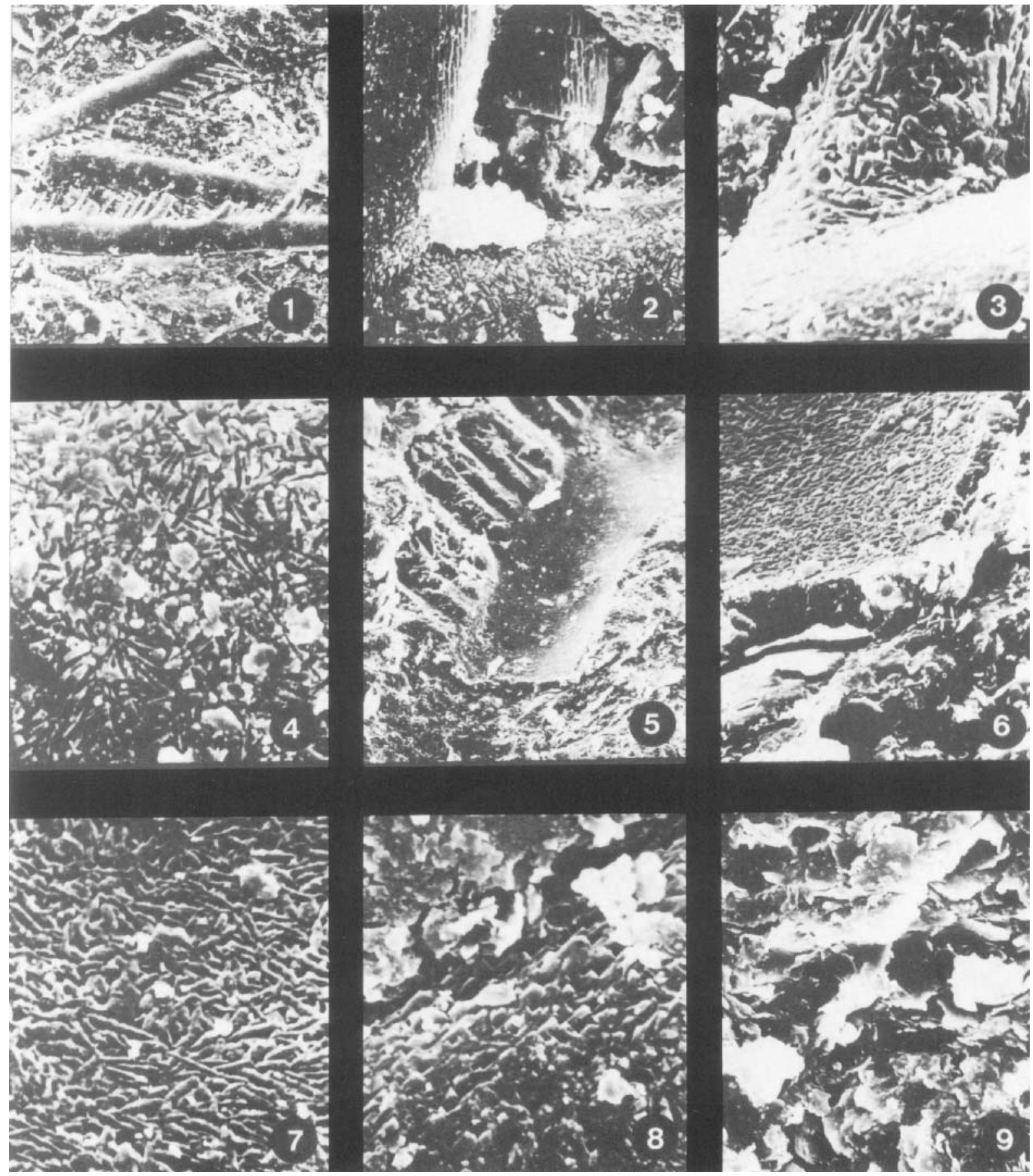

